\title{
セメント系押出成形材料のヤン A PROPOSAL ON PREDICTING グ係数の予測方法の提案 \\ ELASTIC MODULUS OF \\ CEMENTITIOUS MATERIALS \\ PRODUCED BY EXTRUSION \\ MOULDING
}

\section{渡部嗣道 $-* 1$ \\ 守明子—*3 \\ キーワード \\ ヤング係数, 押出成形, セメント系複合体, 複合則, マトリックス, 粒子 \\ 馬場明生 —*2}

Keywords :

Young's modulus, Extrusion moulding, Cementitious composite, Composite law, Matrix, Particle
Tsugumichi WATANABE $-* 1$ Akiko MORI

In this paper, a method for predicting Young's modulus of cementitious composites produced by extrusion moulding is proposed. The applicability of the method was examined by three series of experiments. After the Young's modulus of matrices of composites are predicted, Young's modulus of composites are predicted by Hashin-Hansen equation, which is formed on the basis of Self-Consistent Approximation (S.C.A model) for finding composites mechanism on elastic modulus. Furthermore, it is clarified in case of extrusion moulding that Young's modulus of matrices are deeply influenced by visco additives and fiber additives as well as cement water ratio and degree of hydration. As the result of this experiment, predicted values are nearly equal to tested ones. Therefore, it is possible to predict Young's modulus of cementitious materials produced by extrusion moulding.

よび部材の断面形状によって部材の曲げ用性を予測する方法の確立 が強く求められている。

型枠成形によるコンクリートについては、セメントペーストをマ トリックスとした粒子分散系の複合材料として取り扱った場合のヤ ング係数の予測方法がこれまで多く提案されており、その有効性は 幅広い実験結果によって確認されている[2]。セメント系押出成形材 料もこれと同様に、粒子分散系の複合材料であるために、同方法が 適用できるものと思われるが、押出成形に求められる可塑性・保形 性を確保するために使用される増粘剤や㵶維質添加材などの混和材 料を含むマトリックスの物性や高圧押出成形による異方性の発生に より、型枠成形材料とは異なるものと考えられる。したがって、本 報告では、セメント系押出成形材料のヤンク係数を予測する方法と して、これら型枠成形のコンクリートなどについて提案されている セメント系の粒子分散系複合材料のヤング係数の予測方法をセメン 卜系押出成形材料にも適用し、新しい予測方法を提案する。続いて、 多様な物質・調合についてその妥当性を実験によって検討した。

一方、近年になって、鉄筋コンクリート構造物の型枠材である合 板のその代替部材として、型枠を転用・廃棄するのではなく、型枠 として使用後、そのまま躯体に残す打込み型枠が注目されるように なった。特に、曲げ強度の高いセメント系押出成形部材は、この打 込み型枠構法に適し、多くの開発研究がなされている[1]。この場合、 部材としての曲げ而力のほか、コンクリートの側圧等の施工時の外 力作用に対して所要の寸法精度を確保するため、さらに建設物の完 成後の複合部材としての挙動を明確にするために、曲げ㴊性も重要 になってくる。しかし、セメント系押出成形材料のヤング係数の予 測方法に関する研究はほとんど見られず、成形されることとに実験的 に求められているのが現状である。したがって、使用物質・調合お

\section{2. 型伜成形によるセメント系村料のヤング保数の複合則に関する既往 の研究}

表 1 および図 1 4 4 セ、メント系粒子分散系複合材料のヤング 係数を予測するためにこれまでに提案された代表的な複合モデルを 示す。一般的に、コンクリートは均質等方性のマトリックス相とそ の中に分散している粒子相とからなる 2 相材料と考えられ、そのヤ ング係数は構成相のヤング係数と体積比とで予測する手法が提案さ れている。

直列式と並列式は、図 1 に示すように、それそれ 2 相系複合材料

*1 Assistant Prof., Dpt. of Kansei Design and Engineering, Faculty of Engineering, Yamaguchi Univ., M. Eng.

*2 Prof., Dept. of Kansei Design and Engineering, Faculty of Engineering, Yamaguchi Univ., Dr. Eng.

*3 Prof., Dpt. of Architecture and Civil Engineering, Faculty of Engineering, Nagoya Institute of Technology, Dr. Eng. 
のヤング係数の上限值と下限值とを示すことがよく知られている [3][4][5]。また、図 2 に示すように、Counto はマトリックスの中 心に骨材を配置し、並列モデとと直列モデルとを併用した型で、2 次元複合モデルを提案している[6]。さらに、若林は、これを 3 次元 で表現したモテルを提案している[7]。一方、図 3 に示すように、 0.Ishai は、複合体（コンクリート）中の骨材体積率の此較的小さ な場合の希釈分散系モデルを提案している[8]。これは、セメントペ 一ストのマトリックスの中に粒子として骨材が存在しているモテル であり、複合材のヤング係数はマトリックスのヤンク係数および骨 材体積率に比例して增加する。また、図 4 に示すように、 Self-Consistent Approximation（以下、S.C.A.と記す)によるモデ ルが、T．C.Hansen によって提案された[9]。この考え方は、1つ の粒子とその周囲の複合材料との力学的な相互作用として複合モテ ルを提案することによって、全体系の性質を予測する手法である。 このモテルは、压力を受けている同心球をペーストおよび骨材から なる複合材として考え、その中心に 1 個の骨材を想定した球を存置 し、それと球殻である複合材との力の相互作用を考えるものである。 以上のモテルのうち、S.C.A.モテルによるHashin-Hansen 式が、 型枠成形によるコンクリートのヤング係数の予測式として、広範囲 の物質・調合について最も精度よく適用できることが確認されてい る[2]。

\section{3. セメント系押出成形材料のヤング係数の予湘方法の提案}

セメント系押出成形材料は、型枠成形によるコンクリートと同様 に、粒子分散系 2 相材料として取り扱えると仮定し、これと同様な モデルを使用して、ヤング係数の予測方法を提案する。

図 5 に、ヤング係数の予測フローを示す。まず、増粘剂と繊維質 添加材の種類と混入によってマトリックス固相のヤング係数 $E_{1}$ を 仮定し，製造プロセスにおいて混入した空気量や成形工程における 水量の脱水も考慮した有効水セメント比とセメントの水和率による マトリックスのポロシテ匴出し、(1)式からマトリックスのヤン グ係数 $\mathrm{E}_{\mathrm{a}}$ を予測する。ここで、増粘剂および緎維質添加材をマトリ ックスの一部とし， $\mathrm{E}_{0}$ は押出成形断面形状の影響を受けないことを 前提条件とする。(1)式は、T.C.Powers の3 乗則(Cube Law)として よく知られている。ここに、Em：押出成形材のマトリックスのヤン グ係数, $\mathrm{E}_{1}$ : マトリックスの空腺が雺のときのヤング係数, $\mathrm{Vp}:$ マ トリックスの空隙率, We : 有効水セメント比, $\alpha$ : セメントの水和 率とする。

$$
\begin{aligned}
E m & =E_{l} \cdot(1-V p)^{3} \\
V_{p} & =(W e-0.170 \alpha) /(W e+0.316)
\end{aligned}
$$

（1）式は、T.C.Powers の3 乗則(Cube Law)としてよく知られてい るもので、セメントペーストのヤング係数は、空陌を除いた体積の 3 乗に比例するとするものである[10]。また、マトリックスの空隍 が零のときのヤング係数は、混和材料の種類と量によって異なり、 主にセメント系押出成形材料に特有の材料である、増粘郕と紻維質

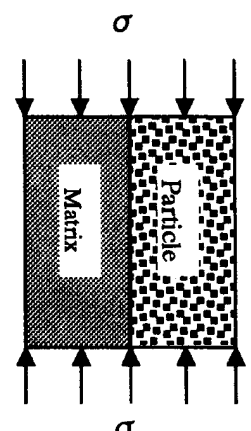

(a) Parallel Model

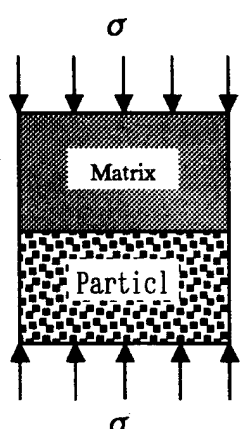

(b) Series Model
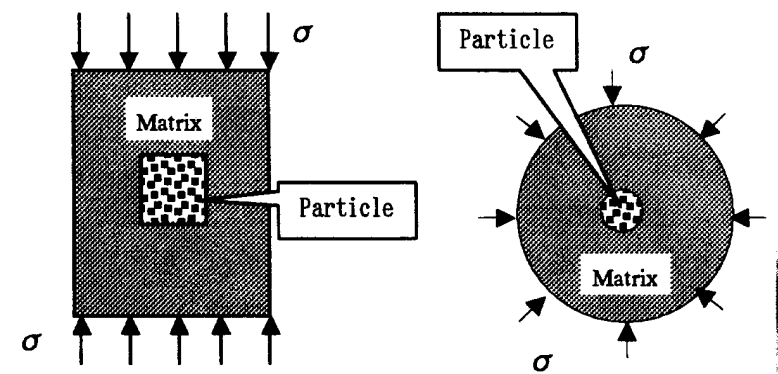

Figure 2 Counto's model

Figure 3 Dilute dispersion model

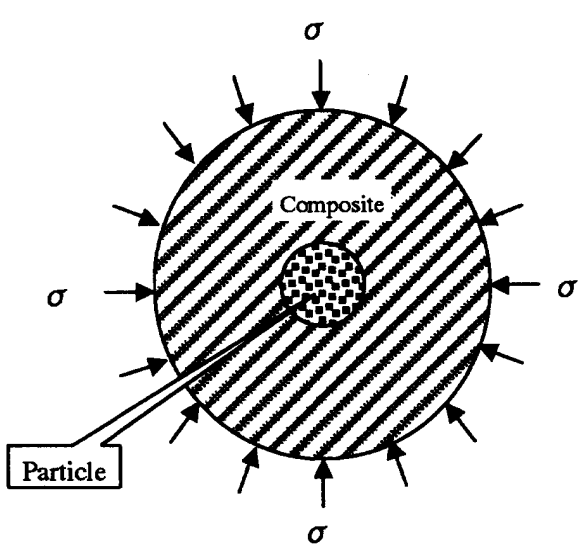

Figure 4 S.C.A. model

\begin{tabular}{|c|c|c|}
\hline Type of model & reseacher(A.D.) & Equations of calculating \\
\hline Parallel model & M.E.De Reus and T.F.Willis (1939) & $E c / E m=1+(n-1) \cdot V a$ \\
\hline Series model & P.Dantu(1957), M.F.Kaplan(1959) & $\mathrm{Ec} / \mathrm{Em}=\mathrm{n} /[\mathrm{n}-(\mathrm{n}-1) \cdot \mathrm{Va}]$ \\
\hline Counto's model & U.J.Counto(1964) & $\mathrm{Ec} / \mathrm{Em}=\left[1+(\mathrm{n}-1) \cdot(\mathrm{Va})^{\wedge} 0.5\right] /\left[1+(\mathrm{n}-1) \cdot\left((\mathrm{Va})^{\wedge} 0.5-\mathrm{Va}\right)\right]$ \\
\hline Wakabayashi'smodel & Minoru Wakabayashi(1960), J.M.Illston(1965) & $\mathrm{Ec} / \mathrm{Em}=\left[1+(\mathrm{n}-1) \cdot(\mathrm{Va})^{\wedge}(1 / 3)\right] /\left[1+(\mathrm{n}-1) \cdot\left((\mathrm{Va})^{\wedge}(2 / 3)-\mathrm{Va}\right)\right]$ \\
\hline Hirshe's model & T.J.Hirsh(1962) & $E c / E m=0.5[1+(n-1) \cdot(V a)]+0.5 n /[n-(n-1) \cdot(V a)]$ \\
\hline Dilute dispersion model & O.Ishai(1962) & $\mathrm{Ec} / \mathrm{Em}=1+\mathrm{C} \cdot \mathrm{Va}$ \\
\hline S.C.A. model & Z.Hashin(1962), T.C.Hansen(1965) & $\mathrm{Ec} / \mathrm{Em}=[\mathrm{n}+1+(\mathrm{n}-1) \cdot \mathrm{Va}] /[\mathrm{n}-1-(\mathrm{n}-1) \cdot \mathrm{Va}] \quad($ Hashin-Hansen 式) \\
\hline
\end{tabular}

Table 1 Past composite law on elastic modulus

Ec : Young's modulus of concrete, $E_{m}$ : Young's modulus of matrices, $E_{a}$ :Young's modulus of aggregate, $n: E_{a} / E_{m}$ (Young's modulus ratio), $\mathrm{Va}:$ Volumetric ratio of aggregate in concrete or mortar 
添加材の影響を受けるものと考えられる。一方、空隙率は、ゲル空 隙・毛細管空隙および連行空気とを加えたものであり、(2)式で計算 する。これは、 $100 \mathrm{~g}$ のセメトが完全に水和する場合には $22.7 \mathrm{~g}$ の水と反応し、その際、水の体櫴が 0.75 倍になるものとして与えら れたものである。また、セメントの水和率の算定は、JIS R 5202 (ポ ルトランドセメントの化学分析方法)によって、まず硬化後の試験体 および使用したセメントの強熱隇量を測定し、その差から結合水量 と自由水量との和を求める。なお、この際、 $\mathrm{CaO}$ と $\mathrm{Si}_{2}$ の量からセ メント量と骨材量とを確認する。続いて、硬化後の試験体中の自由 水量を表乾時と絶乾時との質量差から算出する。結合水量と自由水 量との和とこの自由水量との差から結合水量を計算し、これらの結 果よりセメントの水和率を求める。次に、押出成形材料のヤング係 数は、(1)式で求められたマトリックスのヤング係数と骨材のヤング 係数および骨材の体積率から、(3)式の Hashin-Hansen 式が適用でき るものとして求める。

Ec $/ E m=[n+1+(n-1) \cdot V a] /[n-1+(n-1) \cdot V a]$

\section{4. 模証に用いた実的}

\section{1 使用物質および調合}

使用物質は、結合材料として普通ボルトランドセメントを、骨材 として旧 JIS R 5201(セメントの物理試験方法)の「セメントの強さ 試験法」に用いられていた豊浦硅砂または鋳造用の熊本硅砂を、上 水道水、增粘郕としてメチルセルロース（S N 社製 90SH-4000）、 その他押出成形に標準的な瀻維質添加材としてクリソタイル $6 \mathrm{D}$ (JIS M 8602) および親水性化加エしたポリプロピレン繊維（S D 社製)をそれそれ用いた。表 2 に普通ポルトランドセメント(M社製)、 表 3 に骨材、表 4 に紻維質添加材について、それそれの物性を示す。

モルタルの調合を表 5 に示す。骨材質量に対するセメント質量の 割合を 1.00 の一定とし、水量比 (水量をセメント質量・骨材質量お よび水量の和で除した值)は押出成形可能な全範囲 $0.12 \sim 0.25$ とし た。增粘剤の添加量は、水量比や繊䧽質添加材の種類によらず混和 材料を除いたモルタル総質量に対して $1 \%$ とした。また、繊維質添 加材の添加量は、同様にモルタル総体積の $4 \%$ とした。なお、本実 験は 3 つのシリーズに分けて実施し、シリーズ I は骨材を豊浦硅砂 とし、繊維質添加材の種類を変化させたもの、シリーズIIは瀻維質 添加材をクリソタイルとして骨材の種類を変化させたものである。 また、シリーズIIIはセメントペーストに関するものである。

\section{2 製造方法}

シリーズI およびIIIではアイリッヒミキサ（75 リットル）、シリ 一ズIIではオムニミキサ(30 リットル)で混合した。ここで、アイリ ッヒミキサはオムニミキサよりも均一混合性において優れている。 混合後、スクリュー径 $100 \mathrm{~mm}$ の一軸式ニーダで混練した。混練され

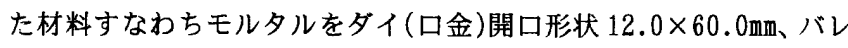
ル内径 $50.0 \mathrm{~mm}$ (ダイ断面/バレル断面積=絞り率 36.7\%)で、バグミ ル部とバレル部の中間に真空室を有する押出成形機にて押し出した。 バグミル部とバレル部のスクリュー回転速度は $11.0 \mathrm{rpm}$ と一定とし た。なお、練混ぜ水量は、脱水や空気の混入などにより、各製造工 程で異なる結果となる。そこで、本実験では、その製造工程ことに 練り混ぜ水量を求め、水セメント比を計算した。

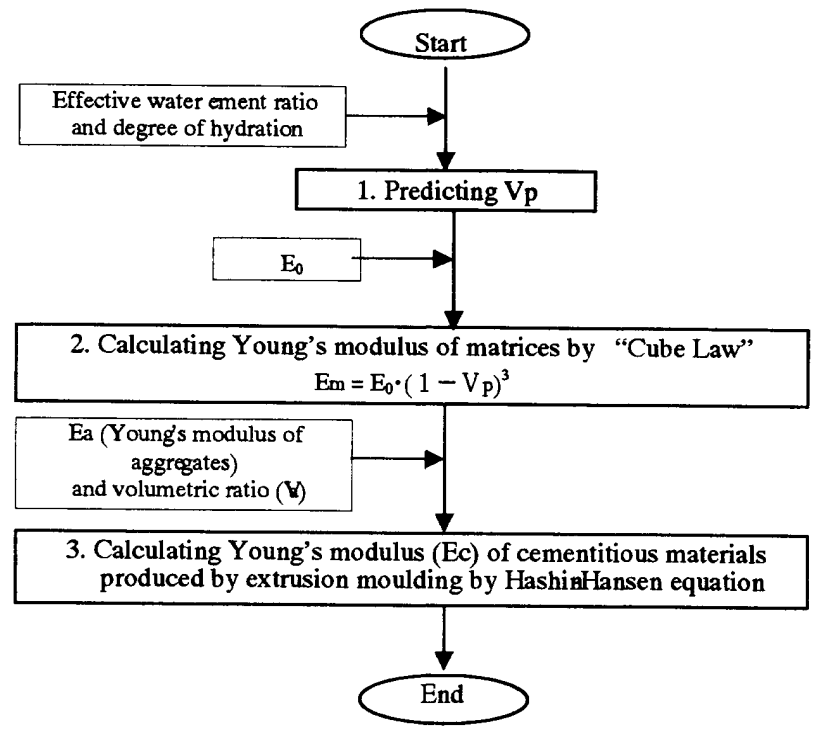

Figure5 Method of predicting Youngs modulus of cementitious materials produced by extrusion moulding

Table 2 Physical properties of ordinary Portland cement

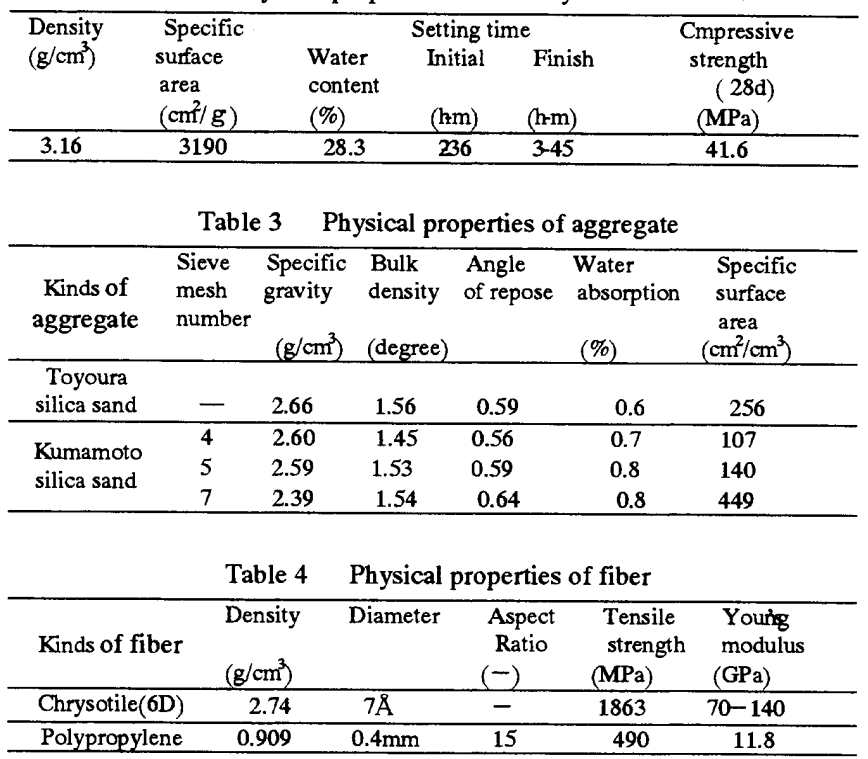

Table 5 Mix proportion of mortals usedin the experiment

\begin{tabular}{|c|c|c|c|c|c|c|c|}
\hline Series & No. & $\begin{array}{l}\text { Kinds of } \\
\text { aggregate }\end{array}$ & $\begin{array}{l}\text { Kinds of } \\
\text { fiber }\end{array}$ & $\begin{array}{l}\text { Water } \\
\text { content } \\
\text { ratio }\end{array}$ & $\begin{array}{l}\text { Water } \\
\text { cement } \\
\text { ratio }\end{array}$ & $\begin{array}{c}\text { Fiber } \\
\text { dditives } \\
\text { content }\end{array}$ & $\begin{array}{l}\text { Methyl } \\
\text { cellulose } \\
\text { content }\end{array}$ \\
\hline \multirow{7}{*}{ I } & 1 & \multirow{7}{*}{$\begin{array}{l}\text { Toyoura } \\
\text { silica sand }\end{array}$} & \multirow{4}{*}{$\begin{array}{c}\text { Chryso } \\
\text {-tile }\end{array}$} & 0.13 & 0.299 & \multirow{4}{*}{0.05} & \multirow{7}{*}{0.01} \\
\hline & 2 & & & 0.15 & 0.353 & & \\
\hline & 3 & & & 0.20 & 0.500 & & \\
\hline & 4 & & & 0.25 & 0.667 & & \\
\hline & 5 & & \multirow{3}{*}{$\begin{array}{c}\text { Polypro } \\
\text { pylene }\end{array}$} & 0.13 & 0.299 & \multirow{3}{*}{0.017} & \\
\hline & 6 & & & 0.15 & 0.353 & & \\
\hline & 7 & & & 0.175 & 0.424 & & \\
\hline \multirow{12}{*}{ II } & 8 & \multirow{4}{*}{$\begin{array}{l}\text { Kumamoto } \\
\text { silica sand } \\
\text { NO.4 }\end{array}$} & \multirow{12}{*}{$\begin{array}{l}\text { Chryso-t } \\
\text { ile }\end{array}$} & 0.12 & 0.276 & \multirow{12}{*}{0.05} & \multirow{12}{*}{0.01} \\
\hline & 9 & & & 0.15 & 0.353 & & \\
\hline & 10 & & & 0.20 & 0.500 & & \\
\hline & 11 & & & 0.25 & 0.667 & & \\
\hline & 12 & \multirow{4}{*}{$\begin{array}{l}\text { Kumamoto } \\
\text { silica sand } \\
\text { NO.5 }\end{array}$} & & 0.12 & 0.273 & & \\
\hline & 13 & & & 0.15 & 0.353 & & \\
\hline & 14 & & & 0.20 & 0.500 & & \\
\hline & 15 & & & 0.25 & 0.667 & & \\
\hline & 16 & Kuma & & 0.12 & 0.273 & & \\
\hline & 17 & moto & & 0.15 & 0.353 & & \\
\hline & 18 & silica sand & & 0.20 & 0.500 & & \\
\hline & 19 & NO.7 & & 0.25 & 0.667 & & \\
\hline III & 20 & - & $\begin{array}{c}\text { Chryso- } \\
\text { tile }\end{array}$ & \multicolumn{2}{|c|}{0.20} & 0.05 & 0.01 \\
\hline
\end{tabular}




\section{3 供試体と曲け試験方法}

押し出された断面 $12.0 \times 60.0 \mathrm{~mm}$ 、長さ約 $550 \mathrm{~mm}$ の長尺な成形体を 水が散逸しないようにヒニールシートで覆い、20ㄷの室内で 1 日封

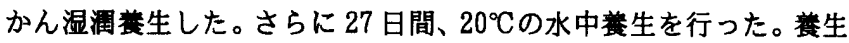
の終了した成形体を長さ $150 \mathrm{~m} \mathrm{~m}$ に切断して曲げ強度测定用供試体 とし、表面の水をウエスで拭い、表乾の状態で曲げ強度試験に供し

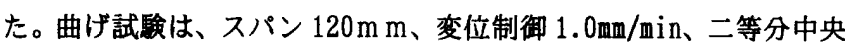
載荷とした。一般に、押出成形材料は異方性材料であると考えられ るが、ここで測定した曲げ強度および戴荷点のたわみは、押出成形 方向のものである。曲げヤンクク係数は、曲げ強度の $1 / 3$ の応力時に おける割線として求めた。ここに、Ec: 実験から求められた押出成 形材料のヤンク係数, P : 最大荷重の $1 / 3$ の荷重, L : 載荷長さ， $\delta$ ： 最大荷重の $1 / 3$ 荷重時の供武体中央部のたわみ，I：試験体の断面 2 次モーメントである。

$$
\mathrm{EC}=\mathrm{P} \cdot \mathrm{L}^{\prime} / 48 \cdot \delta \cdot \mathrm{I}
$$

\section{5. 予测结果}

5.1 マトリックスのヤング係数

シリースIIIのセメントペーストの実験結果について、空陌率が零 のときのヤンク係数の值である実験定数 $\mathrm{E}_{1}$ は瀻維質添加材がクリ ソタイルの場合で 50.7GPa であった。これは、型枠成形のコンクリ 一トのヤング伱数を予測する際に求めたセメントペースト（水とセ メントのみ）からなるマトリックスのヤング係数である 86.8 $\mathrm{GPa}[11]$ を下䢐っている。これは、クリソタイルまたは增粘凨のいず れかの混和材料の影辢と思われる。クリソタイルは硬質でセメント 粒子とほほ同じャング係数と考えられることから、これは增粘剂の 混入がセメント系のマトリックスのヤンク係数を小さくする効果に よるものと思われる。ここでは、押出成形材料で最も一般的な質量 比である $1 \%$ の添加量の場合の $\mathbb{E}_{1}$ の值として上述の值を採用するこ ととした。一方、ボリブロビレンの場合は、その䄉維質添加材のヤ ング俰数がクリソタイルに比べて $1 / 10$ 程度と小さく、体樍率が $4 \%$ もあることから、さらに小さな值となるものと思われる。したがっ て、その $4 \%$ を空陣とみなしてボリブロピレンの場合の $E_{1}$ を求める と $30.7 \mathrm{GPa}$ となった。

\section{2 各種複合モテルの妥当性評価}

マトリックスのヤング係数を求め、次に Hashin-Hansen 式を適用 して、セメント系押出成形材料のヤング係数を求める方法を提案し た。ここでは、セメント系押出成形材料のヤング係数を予測する式 の適用性を見るために、Hashin-Hansen 式のほか各種粒子分散系複 合材料のヤンク係数の予測式について、実験值と計算值とを比較し てその予測精度を評価した。なお、対象とする予測式は、「2.型枠 成形によるセメント系材料のヤング係数の複合則に関する既往の研 究」で述べた(1)直列式, (2)並列式, (3)Counto 式, (4)若林式, (5) Hashin-Hansen 式の 5 式とする。それそれの予測式で計算されたヤ ング係数の計算值は、表 1 に示す計算式を利用して、(5)式で求める。 ただし、骨材のヤング係数は、豊浦硅砂以外の骨材のヤング係数は 既知でないため、本㭲討ではすべての骨材について豊浦硅砂の值で ある $77.5 \mathrm{GPa}[11]$ を用いることとした。ここに、Ec : 押出成形材料 のヤング係数の計算值, $\mathrm{Em}$ ：マトリックス(ペースト)のヤング係数
の予測值， $\mathrm{F}(\mathrm{n}, \mathrm{Va})$ : 各種モデル式で与えられる押出成形材料の マトリックスに対するヤング係数比の計算值, $\mathrm{n}:$ 骨材のヤング係数 のマトリックスのヤング係数に対する比, Va:骨材の容䄼率である。

$$
\begin{aligned}
& \mathrm{Ec} / \mathrm{E}_{\mathrm{m}}=\mathrm{F}(\mathrm{n}, \mathrm{Va}) \\
& \mathrm{Ec}=\mathrm{F}(\mathrm{n}, \mathrm{Va}) \cdot \mathrm{Em}_{\mathrm{m}}
\end{aligned}
$$

\section{3 予測結果}

図 6 の (a)〜 (e)に、各予測式で計算した值と実験值との比較を示 す。並列式および Counto 式による場合の計算值は、ほほあらゆる材 料について実跧值よりも大きな值を示し、特に並列式の場合の両者 の差異は他のモテル式の場合よりも大きな值を示した。これらに奶 し、直列式による場合は、計算值は実験値よりも小さな值を示した。 一方、若林式と S.C.A.モテルによる計算值は、ほほ実験值と同一值 を示した。なお、本実験では、複合材料のヤング係数で約 $5 \sim 30 \mathrm{GPa} 、$ 骨材のマトリックスに対するヤング係数比で 5〜12、骨材の体積率 で 0.25〜0.40 の広範井の条件についての実験結果が得られ、その籍 囲における適用性の確認ができた。

図 7 に、計算值/実験值の变動率を示す。変動率の計算方法は、( 式とした。ここに、N：同一実験因子における供武体数である。 変動率 $=\left(\sum(1-(\text { 計算值 } / \text { 実験值 }))^{2} / \mathrm{N}\right)^{1.5}$

変動率は、いずれの物質・調合に対しても並列モデルが最も大き な值を示した。若林モデルおよびS.C.A モデルが、いずれも 0.2 以 下の最も精度よい結果を示した。

また、物質の種類については、ポリプロピンンの場合と熊本硅杪 7 号の場合とが、やや大きな值を示した。ボリプロヒレンについて はヤング係数を零と仮定したこと、熊本硅砂 7 号については豊浦硅 砂と同等としたという大胆な仮定によるものと見られることが、县 差に結びついたものと思われる。熊本硅砂 7 号の吸水率は大きく、 吸水率の小さな豊浦硅砂のヤング係数に比べ、小さな值を示すもの と思われる。

\section{6.考腺}

6.1 ヤング係数比と計算值/実駼值との比較

図 8 に、マトリックスに対する骨材のヤング係数比と計算值/実狳 值との関係を使用物質毎に示す。並列式による場合は、ヤング係数 比が大きくなるほど、計算值／実䤅值が大きくなるが、他のモテル 式の場合は、ヤング係数比が增大してもほほ一定の值を示した。ま た、並列式の場合、他のモテル式による場合よりも 1.5〜4.5 程度と いう非常に大きな值を示した。これに対して他のモデル式は、ヤン グ係数比にかかわらず 0.8 1.5 程度の值を示し、特に若林式と S.C.A.モテルの場合にはほほ 1.0 の值を示した。以上の傾向は 5 種 類の使用物質の組合わせのいずれについても同様の傾向が得られた。

\section{2 骨材体糟率と計算值／実験值との比較}

図 9 に、骨材体樍率と計算值/実験值との関係を使用物質毎に示 す。並列式による場合は、骨材体糟率 Va が大きくなるほど、計算值 /実験值が小さなる傾向を示したが、他のモデルの場合は、骨材 体積率の增大にかかわらず、Va が 0.25〜0.40の範囲においてほほ 一定の值を示した。これらの傾向は、5 種類の使用物質の組み合わ せについて、いずれも同様の傾向が得られた。 


\section{3 セメント系押出成形材料のヤング係数の予測}

図10にT.C.P owersの3 乗則によるマトリックスのヤンク係数の 予測值を示す。本実験の結果、押出成形可能な水量比の範囲につい て、マトリックスの空隙率の計算值は $0.36 \sim 0.56$ となり、 $E_{m}$ の予 測值は繊維質添加材がクリソタイルの場合 $\left(\mathrm{E}_{0}=50.7 \mathrm{GPa}\right)$ で約 $5 \sim$

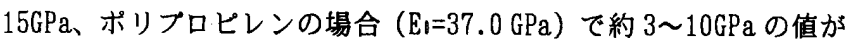
得られた。

図 11 に緎維質添加材がクリソタイルの場合、図 12 に絽維質添加 材がポリフロピレンの場合の Hashin-Hansen 式によって計算された 押出成形材料のヤング係数の予測值をそれそれ示す。ここで、図 7 で示されたように骨材のマトリックスに対するヤング係数の此は、 クリソタイルおよびポリブロヒレンともに5〜20 GPaであった。ま た、マトリックスのヤング係数は、図10で示された範囲の値となっ た。この結果、セメント系の押出成形材料のヤング係数の範囲は、 繊維質添加材がクリソタイルの場合で 6〜30 GPa、ポリプロピレン の場合で 5〜20 GPaであった。

\section{7. まとめ}

本研究では、コンクリートなどの型枠成形材のヤング係数に関す る複合モデルを適用し、セメント系押出材料のヤング係数の予測方 法を提案し、その適用性を実験によって確認した。その結果、以下 の結諭を得た。

(1)セメント系押出材料のヤング係数の予測方法を提案した。それは、 T.C.Powers の3 乗則でマトリックスのヤング係数を予測した後、 セメント系粒子分散材料の複合則の一つである Hashin-Hansen 式 によって求める方法である。

(2)本提案方法を検証するために、押出成形可能な全水量比の範囲に ついて曲げ実験を実施した。その結果、増粘剂の添加によってマ トリックスのヤング係数が低下した。

（3）本実験条件の範囲において、空隙率が零のときのマトリックスの

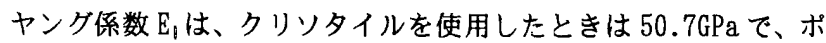
リプロピレンを使用したときは 37.0GPaであった。

(4)セメント系押出成形材料のヤング䋆数を予测するために、マトリ ックスのヤング係数、骨材のヤング係数および体積率から、型枠 成形によるコンクリートのヤング係数を予測するための複合則で 知られている 5 種類のモデル式を用いた。その結果、若林モデル とS.C.A.モデルを適用できることが確認された。

\section{[参考文献]}

[1]馬場明生活か：薄肉打込み型枠工法ガイドライン，建設省建築研究所建策 研究報告, 1995 年 8 月

[2]岸谷孝一，馬場明生 : 建築材料の乾煤収縮機構，セメントコンクリート， No.346, pp.30-39, 1975.12

[3]M.E.DeRews, T.F.Wills : Themal Volume Chamge and Elasticity of Aggregates and their Effect on Concrete, Pro. of ASTM

[4]P.Dantu : Etude des Contraintes dans les Milieux Heterognes, Ann. Tech. Batimant Jraw, Publ. Vollil, 1958

[5] M.F.Kaplan : Utrasonic Pulse Velocity, Dynamic Modulus of Elasticity, Poisson's Ratio and the Strength of Concrete Made with Thirteen Different Cements' Aggregates, Rilem Synpo. Paris, 1959

[6]U.J.Counto: The Effect of the Elastic Modulus of the Aggrgate on the Elastic Modulus, creep and creep recovery of concrete, MCR.16,1964

[7]若林 実: コンクリートのヤング係数に関する材料の影境について,日本 建策学会諭文報告集, No.66, 1960

[8]O.Ishai : Influence of Sand Concentration on Deformations of Mortar Beams Under Low Stress, J. of ACI , Vol.58, No6, 1961
[9]T.C.Hansen : Influence of Aggregate and Void on Modulus of Elasticity of Concrete, Cement Mortar and Cement Past, J. of ACI, Vol.62, No.2, 1965 [10]T.C.Powers,T.L.Brownyard: Studies of the Physical Properties of Hardened Portoland Cement Pastes, J. of ACI, 1948

[11]Akio Baba: Drying Shrinkage Mechanism of Building Materials, BRI Research Paper No.77, March.1978

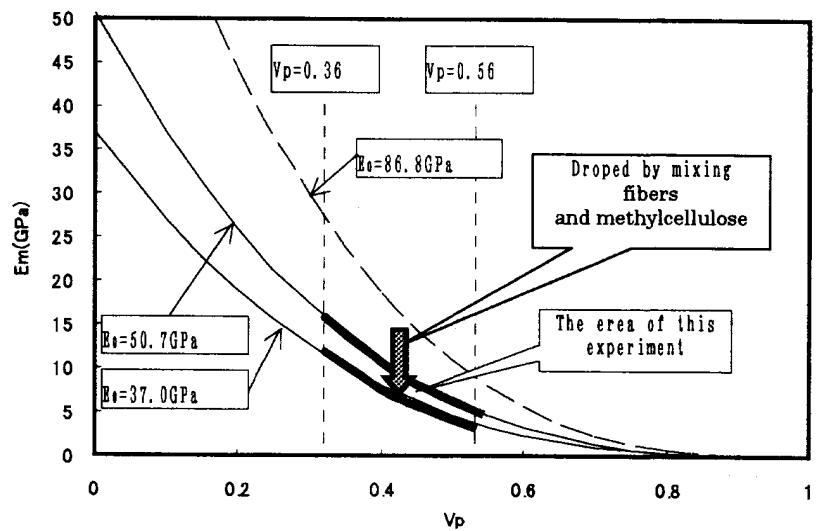

Figure 10 Relationship between $V_{D}$ and $E_{m}$

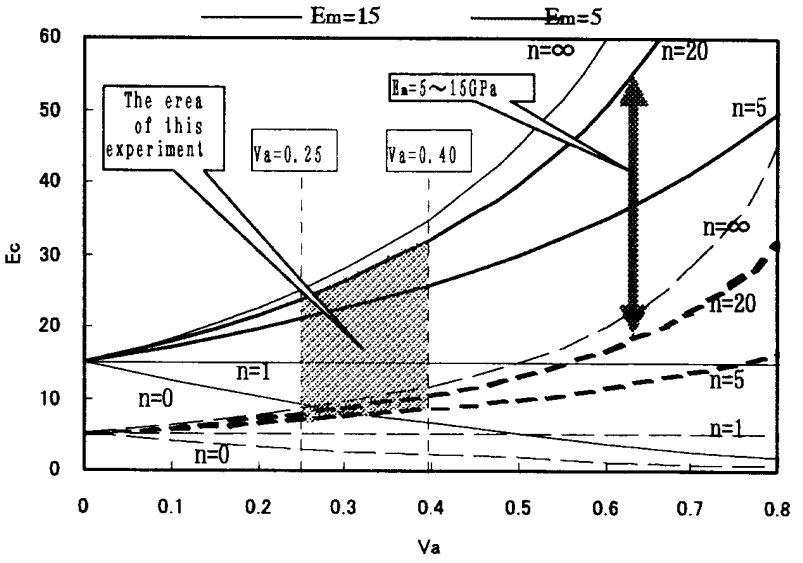

Figure 11 Relationship between $\mathrm{V}_{\mathrm{a}}$ and $\mathrm{E}_{\mathrm{C}}$ (Fiber : chrysotile)

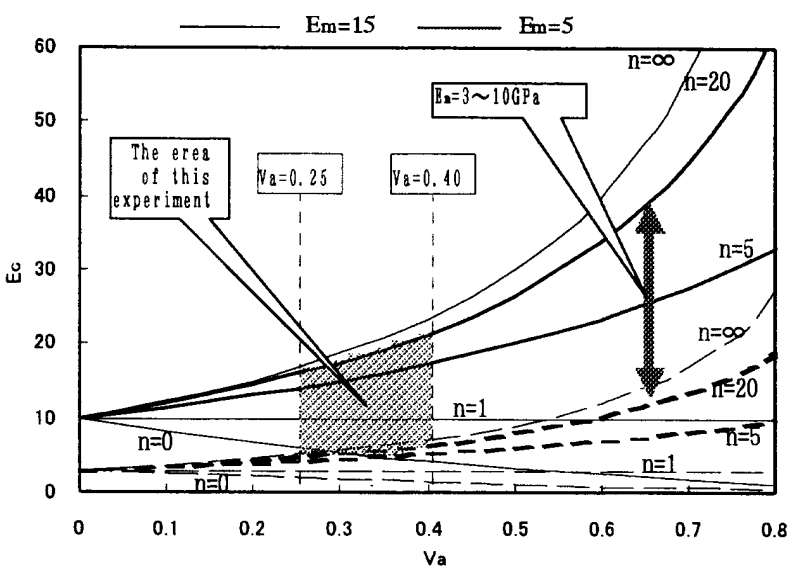

Figure 12 Relationship between $V_{a}$ and $E_{C}$ (Fiber : polypropylene) 
Toyoura silica sand $\triangle$ Polypropylene $\square$ Kumamoto silica sand NO.4 $\diamond$ Kumamoto silica sand NO5 Kumamoto silica sand NO.7

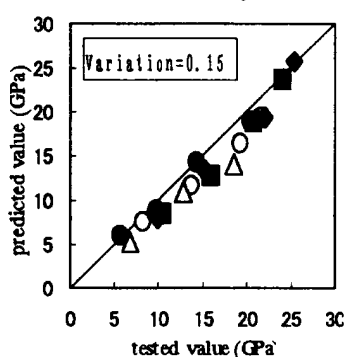

(a) Series model

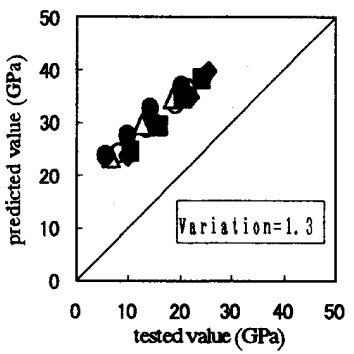

(b) Parallel model

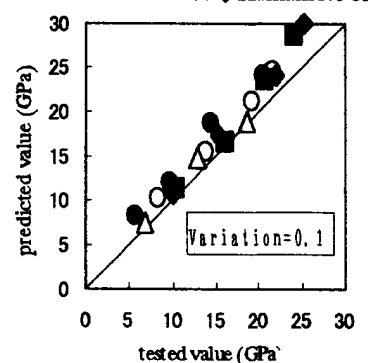

(c)Counto's model

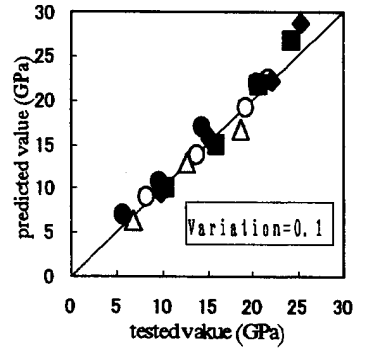

(d)Wakabayashi's model

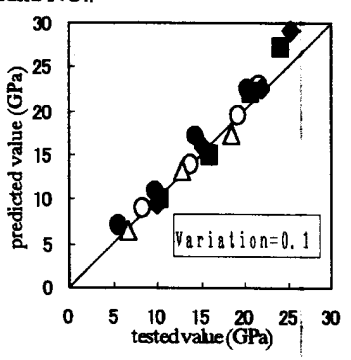

(e)S.C.A. model

Figure 6 Experimental examination of composite laws on Youngs modulus (overall test results)

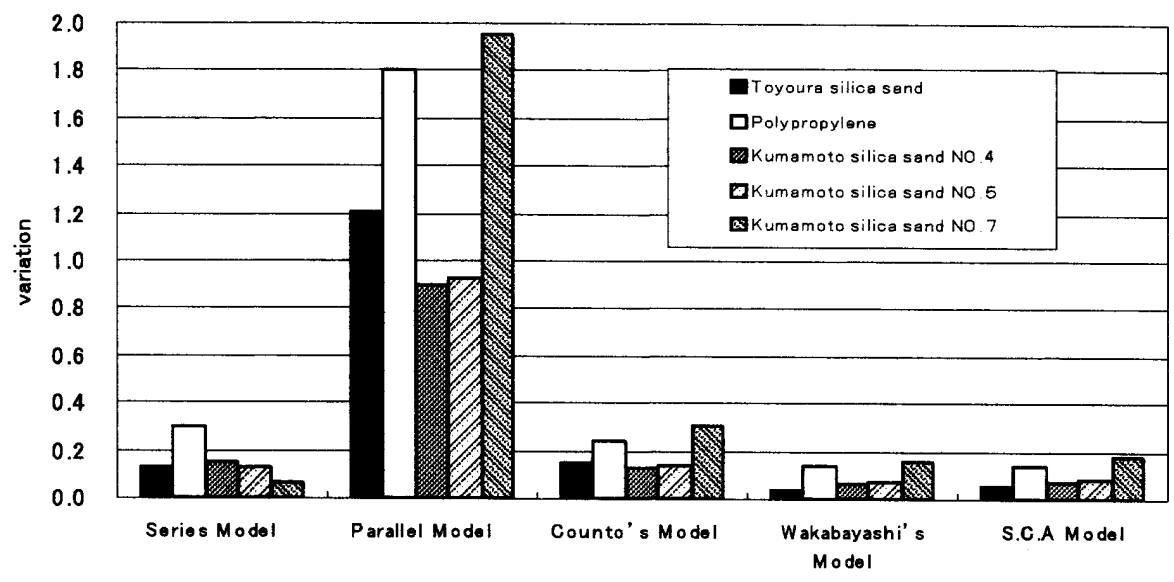

Figure 7 Variation of predicted value

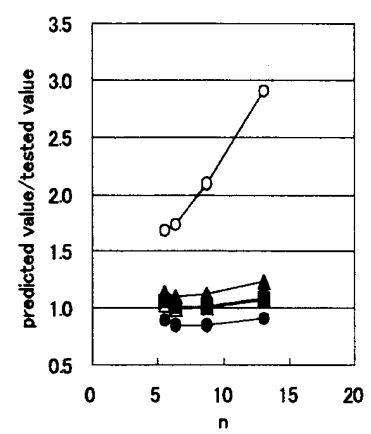

(a) chrysotile and Toyoura silica sand

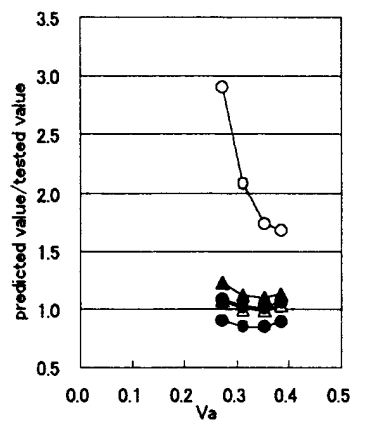

(a) chrysotile and Toyoura silica sand

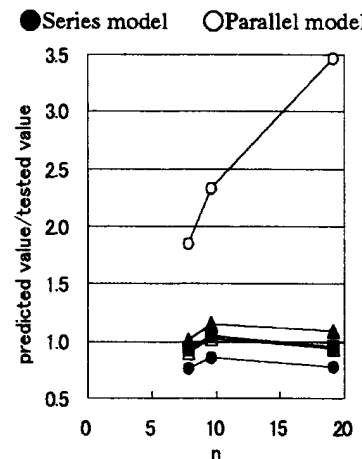

(b)Polypropylene and
Toyoura silica sand

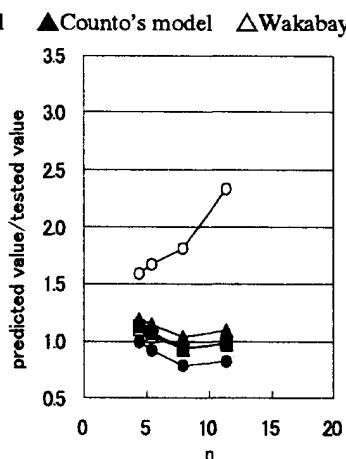

(c) chrysotile and

Kumamoto silica sand NO.4

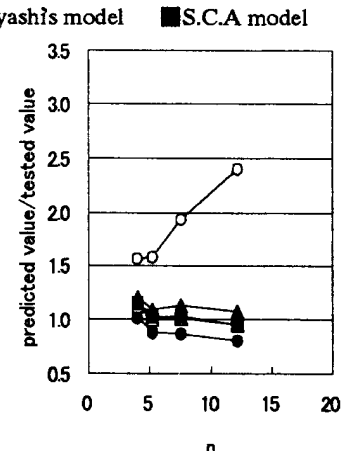

(d) chrysotik and

Kumamoto silica sand NO. 5

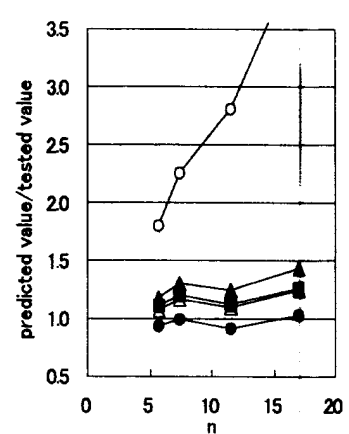

(e) chrysotile and

Kumamoto silica sand NO. 7

Figure8 Experimental examination of composite dws on Young's modulus (influence of $n$ )

OSeries model OParallel model

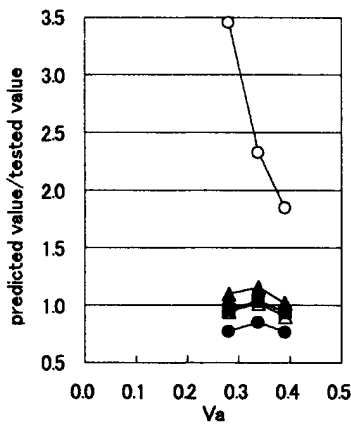

(b)Polypropylene and

Toyoura silica sand

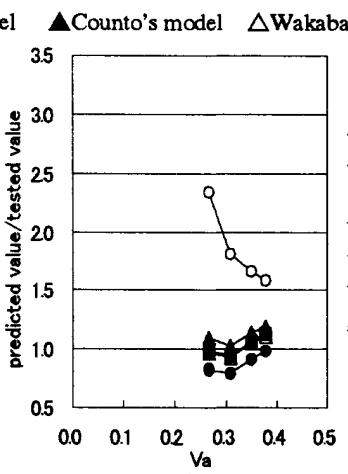

(c) chrysotile and

Kumamoto silica sand NO.

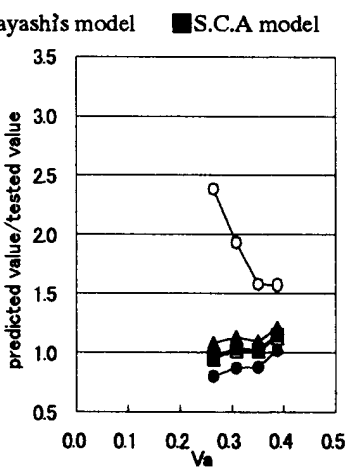

(d)chrysotile and Kumamoto silica sand NO. 5

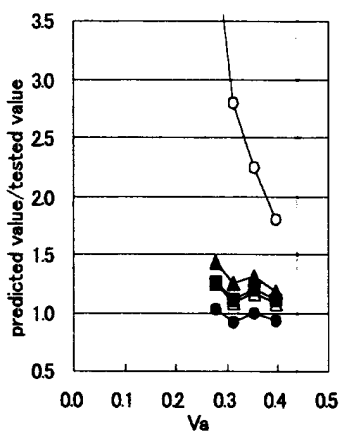

(e) chrysotile and Kumamoto silica sand NO. 7

Figure 9 Experimental examination ofcomposite laws on Youngs modulus (influence of Va) 